\title{
Teaching a Computer Science Course using Adaptable Instructional Images
}

\author{
Stavros K. Filippidis ${ }^{1}$, and Ioannis A. Tsoukalas ${ }^{2}$ \\ ${ }^{1}$ Multimedia Lab, Department of Informatics, Aristotle University of \\ Thessaloniki, \\ GR-54124 Thessaloniki, Greece \\ sfilippiecsd.auth.gr \\ ${ }^{2}$ Multimedia Lab, Department of Informatics, Aristotle University of \\ Thessaloniki, \\ GR-54124 Thessaloniki, Greece \\ tsoukala@csd.auth.gr
}

\begin{abstract}
In this paper, we use adaptable instructional digital images. The images used are the result of screen capture. These images illustrate the specific use of a spreadsheet software package in order to complete a given task. This task consists from several parts, and for these parts the corresponding images are given in different versions. Each version is using a different amount of details for the same part of the task. The task is accessible to the students through a single html file hosted on a web site, available through an Intranet. Via this web site students choose their preferable "knowledge path" (that is: the choice of image files they make in order to view the whole task). In the experimental course set, there are 3 steps where students choose between 2 versions for each, giving altogether 8 different choices (knowledge paths) that a student can choose from.
\end{abstract}

\section{Introduction and Theoretical Analysis}

Research has been performed in many aspects of using animation, multimedia and video for instruction, as well as relative issues of pedagogy and didactics on children [1-12]. Research has also been performed in many aspects of adaptive and adaptable hypertext, hypermedia and multimedia [13-18]. In this paper, we use adaptable instructional images (that is: in this system students adapt to the system themselves while using it). The approach we use here makes the assumption that the adaptation has to be performed without changing the media used to present a certain knowledge item. For example, a concept we found out that is best to be taught using instructional images, will not be presented as well if we choose to teach it using digital audio (e.g.: aural instructions). So, in order to use adaptation to give different knowledge paths to each student, we do not change the used media itself; we prefer

Please use the following format when citing this chapter:

Filippidis, Stavros, Tsoukalas, Ioannis, 2006, in IFIP International Federation for Information Processing, Volume 204, Artificial Intelligence Applications and Innovations, eds. Maglogiannis, I., Karpouzis, K., Bramer, M., (Boston: Springer), pp. 401-408 
to change the content of the certain media. This assumption and approach was followed by [14] (where it was used for the case of adaptable instructional video). In the case of this experiment, we change the content of the instructional images. By the term "knowledge path" we are referring to the 8 different choices a student can make: Considering that there are 3 steps where students choose between 2 versions for each, there are altogether $2 * 2 * 2=8$ different choices.

By making different versions of instructional images for the same part of the course, we provide different levels of detail to students: Students can either choose the non - detailed images (they only view the result of the certain part of the task) or the detailed version of the images.

Students can choose a sequence of instructional images all based on the same approach, or they can choose images using each time the appropriate alternative version.

The method of instruction uses adaptation (alternative images for the same part of the task) and gives the student more flexibility in order to adapt this method to his/her personal needs. So, the students can create their own knowledge path and they can use it to complete the given task taking all the time they need. This method is similar to the method used by [14] (where it was used for the case of adaptable instructional video).

\section{The experiment}

We used the described method in order to teach a course on spreadsheets to high school students. In this course, students have to calculate the remaining amount of euros to be paid, from someone who got a loan from a bank, at the end of a given period. We divided this exercise into ten (10) steps, and some of the steps had different approaches (and different versions of images).

The goals of the experiment are to examine the following: Did students find the applied method useful, easy to use, and easy to learn and did they feel satisfied using it? Are the results of the students relevant among these categories (usefulness, ease of use, ease of learning, and satisfaction)? Is there any difference in terms of using the detailed version of images or not?

The steps and approaches are as follows.

\subsection{The Steps of the Given Task}

For the first step, students have to create the initial spreadsheet (table) and enter headings and data to it. This step has a limited number of special actions to be performed in the spreadsheet: Merging cells, formatting cells and enter initial data of the task. For this first step, two different versions of images were used.

In the first approach, we presented an image containing the completed screenshot of the spreadsheet for this step. In the second approach, we presented a series of 15 images that presented, in detail, what the students had to do in order to complete the first step. 
For steps 2-6, students have to calculate the result of some cells by typing the proper types (e.g.: $=\mathrm{C} 1+\mathrm{D} 2)$. For these steps, two different versions of images were used.

In the first approach, we presented images (one for each step) containing the completed screenshot of the spreadsheet for these steps. In the second approach, we presented a series of 10 images (two for each step) that presented, in detail, what the students had to do in order to complete these steps.

For steps $7-10$, students have to calculate the rest of the cells by using the completion method. For these steps, two different versions of images were used.

In the first approach, we presented images (one for each step) containing the completed screenshot of the spreadsheet for these steps. In the second approach, we presented a series of 6 images that presented, in detail, what the students had to do in order to complete these steps.

\subsection{Experimental Setup}

The experimental setup is similar to the experimental setup used by [14] (where it was used for the case of adaptable instructional video). We used all the above images to create our experiment: We created a single (and very simple to use) web page (html file). Please note that in this experiment we didn't use any special authoring environment. In this html file, we gave instructions to the students (subjects of the experiment) about the steps they had to follow in order to complete the given task. For each step, simple (text) instructions were given: These instructions were about the contents of each of the images (alternative versions) available on every step, so that the students could choose the proper version of the images they would like to view for each of the steps. This html file and the corresponding image files were available to the students through an intranet. Each of the students completed the given task by following the instructions and viewing the image files (available through the html file).

The method was applied to 43 high school students. After completing the given task, each student completed a questionnaire about how he/she evaluated the method of instruction. We used the USE questionnaire [20]. We used all statements from this questionnaire [20], except one that did not fit our case of study. The word "it" in the USE questionnaire [20] was changed to "this method" (the use of adaptable digital images for instruction).

In this questionnaire, the students had to rate their agreement with the given statements about how they felt using this method of instruction. For each statement, they had to circle or $X$ out the level of agreement that applied (where 1 means strongly disagree, 4 means neither disagree nor agree, and 7 means strongly agree; and NA means it doesn't apply). Finally, the option of not rating a statement was given (by cycling nothing or by cycling the "NA" option).

Also, in each questionnaire the students completed yes or no to the question "did you use the detailed version of the images?", and also their sex (male or female).

This type of questionnaire had been used by [14] and [19]. 


\section{Statistical Analysis and Results}

\subsection{Grouping Initial Statements of the Questionnaire into Categories}

In order to group these statements into categories for further statistical analysis, we grouped them into four categories, using the categories as they appear in [20]:

Category 1: Usefulness

Category 2: Ease of Use

Category 3: Ease of Learning

Category 4: Satisfaction

For each of these categories, we calculated the mean value of all the statements of the category, and we used this mean value as the value of the category.

So, further statistical analysis was performed using these four categories, and not the 29 initial statements. In fact, we transformed the 29 discrete variables we initially had (from the questionnaires) into 4 non-discrete variables.

This kind of transformation had also been performed to the questionnaire used by [14] and [19].

Please note that for some of the statistics that follow, we recoded these 4 nondiscrete variables into discrete variables for statistical purposes.

\subsection{Statistical Results and Correlations between Categories}

The boxplots for the four categories are given in figure 1. Statistical facts for the four categories are given in table 1 . In table 2 we see correlations between the categories (in pairs of two). We see that they are (in pairs of two) related with correlations significant at the 0.01 level (2-tailed).

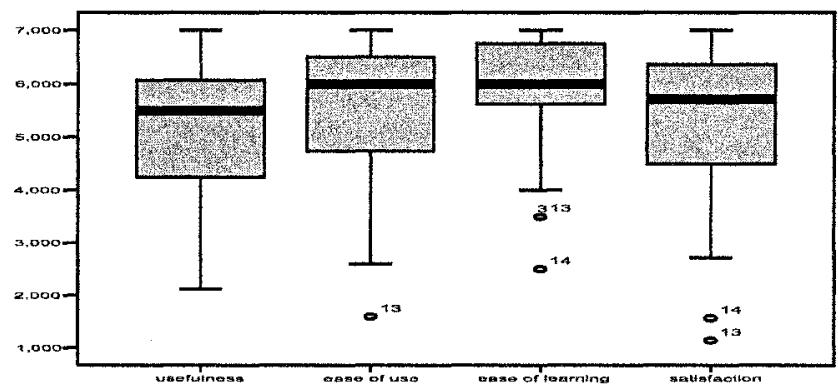

Fig. 1. Boxplots for the four categories 
Table 1. Statistical facts for the four categories

\begin{tabular}{llllll}
\hline & & \multicolumn{3}{l}{ Ease of } \\
& & Usefulness & Ease of use & learning & Satisfaction \\
\hline N $\quad$ Valid & 43 & 43 & 43 & 43 \\
\multicolumn{1}{c}{ Missing } & 0 & 0 & 0 & 0 \\
Mean & 5.19 & 5.56 & 5.86 & 5.28 \\
Std. Error of Mean & 0.86 & 0.177 & 0.190 & 0.222 \\
Std. Deviation & 1.220 & 1.161 & 1.246 & 1.453 \\
Skewness & -0.786 & -0.962 & -1.352 & -1.052 \\
Std. Error of Skewness & 0.361 & 0.361 & 0.361 & 0.361 \\
Kurtosis & 0.462 & 0.925 & 1.566 & 0.710 \\
Std. Error of Kurtosis & 0.709 & 0.709 & 0.709 & 0.709 \\
Percentiles & 10 & 4.00 & 4.00 & 4.00 & 3.00 \\
& 25 & 4.00 & 5.00 & 5.00 & 4.00 \\
& 50 & 5.00 & 6.00 & 6.00 & 6.00 \\
& 75 & 6.00 & 6.00 & 7.00 & 6.00 \\
& 90 & 6.60 & 7.00 & 7.00 & 7.00 \\
\hline
\end{tabular}

Table 2. Correlations between the categories

\begin{tabular}{|c|c|c|c|c|c|}
\hline & & usefulness & $\begin{array}{c}\text { ease of } \\
\text { use }\end{array}$ & $\begin{array}{l}\text { ease of } \\
\text { learning }\end{array}$ & satisfaction \\
\hline \multirow[t]{3}{*}{ usefulness } & $\begin{array}{l}\text { Pearson } \\
\text { Correlation }\end{array}$ & 1 & $0.828(* *)$ & $0.757\left(^{* *}\right)$ & $0.921\left(^{* *}\right)$ \\
\hline & Sig. (2-tailed) & $\cdot$ & 0.000 & 0.000 & 0.000 \\
\hline & $\mathrm{N}$ & 43 & 43 & 43 & 43 \\
\hline \multirow[t]{3}{*}{ ease of use } & $\begin{array}{l}\text { Pearson } \\
\text { Correlation }\end{array}$ & $0.828(* *)$ & 1 & $0.902(* *)$ & $0.929(* *)$ \\
\hline & Sig. (2-tailed) & 0.000 & . & 0.000 & 0.000 \\
\hline & $\mathrm{N}$ & 43 & 43 & 43 & 43 \\
\hline \multirow[t]{3}{*}{$\begin{array}{l}\text { ease of } \\
\text { learning }\end{array}$} & $\begin{array}{l}\text { Pearson } \\
\text { Correlation }\end{array}$ & $0.757(* *)$ & $0.902\left(^{* *}\right)$ & 1 & $\left.0.8399^{* *}\right)$ \\
\hline & Sig. (2-tailed) & 0.000 & 0.000 & . & 0.000 \\
\hline & $\mathrm{N}$ & 43 & 43 & 43 & 43 \\
\hline \multirow[t]{3}{*}{ satisfaction } & $\begin{array}{l}\text { Pearson } \\
\text { Correlation }\end{array}$ & $0.921(* *)$ & $0.929(* *)$ & $0.839(* *)$ & 1 \\
\hline & Sig. (2-tailed) & 0.000 & 0.000 & 0.000 & \\
\hline & $\mathrm{N}$ & 43 & 43 & 43 & 43 \\
\hline
\end{tabular}

** Correlation is significant at the 0.01 level (2-tailed). 


\subsection{Independent Samples Test}

We made independent samples t-test to check whether the mean values of the four categories differ significantly in terms of using detailed version of images or not. In table 3 we see group statistics using the details as grouping variable.

Table 3. Grouping statistics (grouping variable: details used)

\begin{tabular}{llllll}
\hline & details used & $\mathrm{N}$ & Mean & Std. Deviation & Std. Error Mean \\
\hline usefulness & detailed & 29 & 5.06158 & 1.190709 & 0.221109 \\
& simple & 13 & 5.65385 & 1.092295 & 0.302948 \\
ease of use & detailed & 29 & 5.45517 & 1.324157 & 0.245890 \\
& simple & 13 & 5.87350 & 0.932766 & 0.258703 \\
ease of learning & detailed & 29 & 5.80172 & 1.263109 & 0.234553 \\
& simple & 13 & 6.21154 & 0.518875 & 0.143910 \\
satisfaction & detailed & 29 & 5.14778 & 1.486324 & 0.276003 \\
& simple & 13 & 5.60440 & 1.293829 & 0.358844 \\
\hline
\end{tabular}

In table 4, we see results for Levene's test for equality of variances.

Table 4. Levene's test for equality of variances (Equal variances assumed)

\begin{tabular}{lll}
\hline & F & Sig. \\
\hline usefulness & 0.014 & 0.905 \\
ease of use & 1.269 & 0.267 \\
ease of learning & 6.228 & 0.017 \\
satisfaction & 0.192 & 0.664 \\
\hline
\end{tabular}

We can see that sig $>0.10$ for categories usefulness, ease of use and satisfaction, so we can assume equal variances for these categories. Also, we can see that sig $<0.10$ for category ease of learning, so we can not assume equal variances for this category.

So, the independent samples t-test for our case is given in table 5 .

Table 5. Independent samples t-test

\begin{tabular}{lllllll}
\hline & & & & $\begin{array}{l}\text { Sig. (2- } \\
\text { tailed) }\end{array}$ & $\begin{array}{c}\text { Mean } \\
\text { Difference }\end{array}$ & $\begin{array}{l}\text { Std. Error } \\
\text { Difference }\end{array}$ \\
\hline usefulness & $\begin{array}{l}\text { Equal } \\
\text { variances } \\
\text { assumed } \\
\text { Equal }\end{array}$ & -1.527 & 40 & 0.135 & -0.592270 & 0.387867 \\
ease of use & $\begin{array}{l}\text { Equal } \\
\text { variances } \\
\text { learning }\end{array}$ & -1.027 & 40 & 0.310 & -0.418332 & 0.407204 \\
assumed & $\begin{array}{l}\text { Equal } \\
\text { variances } \\
\text { notisfaction assumed }\end{array}$ & -1.489 & 39.867 & 0.144 & -0.409814 & 0.275182 \\
& $\begin{array}{l}\text { Equal } \\
\text { variances } \\
\text { assumed }\end{array}$ & -0.956 & 40 & 0.345 & -0.456612 & 0.477731 \\
\hline
\end{tabular}


We can see that $\operatorname{sig}(2$-tailed $)>0.05$ so the mean values of the four categories do not differ significantly in terms of using the detailed version of images or not.

\section{Conclusions}

To begin with, as we can see in table 1 the mean values for the four categories usefulness, ease of use, ease of learning and satisfaction are, respectively, 5.19, 5.56, 5.86 , and 5.28. So, considering that these values are $>4$, we can say that students found the applied method useful, easy to use, easy to learn and they felt satisfied using it.

As we can see from table 2, correlation is significant between the four categories (in pairs of two). So, the results of the students are relevant among the categories. So, we can say - for example - that if a student is satisfied with the applied method, then we expect that he/she would find it useful as well.

Finally, from table 5 we conclude that the mean values of the four categories (usefulness, ease of use, ease of learning, and satisfaction) do not differ significantly in terms of using the detailed version of images or not.

\section{References}

1. Bolhuis, S., Voeten, M. J. M.: Toward self-directed learning in secondary schools; what do teachers do? Teaching and Teacher Education, 17 (2001) 837-855.

2. Crawford, R.: Teaching and learning IT in secondary schools: towards a new pedagogy? Education and Information Technologies, 4, IFIP (1999) 49-63.

3. Downes, T.: Children's Participation in Evaluating the Role of New Information and Communication Technologies in Schools. Education and Information Technologies, 4:3 (1999) 331-341.

4. Furr, P. F., Ragsdale, R. G.: Desktop Video Conferencing. How to Avoid Teacher and Student Frustration. Education and Information Technologies, 7:4 (2002) 295-302.

5. Knezek, G., Christensen, R.: Impact of New Information Technologies on Teachers and Students. Education and Information Technologies, 7:4 (2002) 369-376.

6. Mayer, R. E., Moreno R.: Animation as an Aid to Multimedia Learning. Educational Psychology Review, Vol. 14, No. 1 (2002) 87-99.

7. Mumtaz, S.: Children's Conceptions of Information Communications Technology. Education and Information Technologies, 7:2 (2002) 155-168.

8. Passig, D., Levin, H.: The Interaction between Gender, Age, and Multimedia Interface Design. Education and Information Technologies, 6:4 (2001) 241-250.

9. Schraw, G., Flowerday, T., Lehman, S.: Increasing Situational Interest in the Classroom. Educational Psychology Review, Vol. 13, No. 3 (2001) 211-224.

10. Selwyn, N.: Students' attitudes towards computers in sixteen to nineteen education. Education and Information Technologies, 4:2 (1999) 129-141.

11. Watson, D. M.: Pedagogy before Technology: Re-thinking the Relationship between ICT and Teaching. Education and Information Technologies, 6:4 (2001) 251-266.

12. Webb, M. E.: Pedagogical Reasoning: Issues and Solutions for the Teaching and Learning of ICT in Secondary Schools. Education and Information Technologies, 7:3 (2002) 237255.

13. Cristea, A. I.: What can the Semantic Web do for Adaptive Educational Hypermedia? Educational Technology \& Society, 7(4) (2004) 40-58. 
14. Filippidis, S. K., Tsoukalas, I. A.: Adaptable Instructional Video: Using Instructional Video with Adaptable Content to Teach a Computer Science Course. In Proceedings of IADIS International Conference "Cognition and Exploratory Learning in Digital Age" (CELDA2005), (2005) accepted for publication.

15. Lin, C.-B., Young, S. S.-C., Chan, T.-W., Chen, Y.-H.: Teacher-oriented adaptive Webbased environment for supporting practical teaching models: a case study of "school for all". Computers \& Education, 44 (2005) 155-172.

16. Papanikolaou, K. A., Grigoriadou, M., Magoulas, G. D., Kornilakis, H.: Towards new forms of knowledge communication: the adaptive dimension of a web-based learning environment. Computers \& Education, 39 (2002) $333-360$.

17. Papasalouros, A., Retalis, S., Papaspyrou, N.: Semantic Description of Educational Adaptive Hypermedia based on a Conceptual Model, Educational Technology \& Society, 7(4) (2004) $129-142$.

18. Triantafillou, E. Pomportsis, A., Demetriadis, S.: The design and the formative evaluation of an adaptive educational system based on cognitive styles. Computers \& Education, 41 (2003) $87-103$.

19. Filippidis, S., Tsoukalas, I.: Using Digital Video as an Asynchronous Method of Instruction. In Proceedings of The 3rd IEEE International Conference on Advanced Learning Technologies (ICALT'03) (Athens, Greece, July 09 - 11, 2003) 130-134.

20. Lund, A. M.: Measuring Usability with the USE Questionnaire. Usability Interface, STC Usability and User Experience Community, Vol.8, No. 2 - Success Stories (October 2001), http://www.stcsig.org/usability/newsletter/0110 measuring with_use.html 